\title{
Long-Run Elasticity of the Substitution in the Slovak Economy
}

\author{
Karol Szomolányi \\ University of Economics Bratislava, Slovakia \\ Martin Lukáčik \\ University of Economics Bratislava, Slovakia \\ Adriana Lukáčiková \\ University of Economics Bratislava, Slovakia
}

\section{Abstract}

The value of the Slovak long-run elasticity substitution is relatively slow - about 0.10. It follows from the estimate of low-frequency econometric model. Econometric form is given by the capital demand derived from the first-order conditions of the firm maximizing its profit. Due to the robustness we use different measures of the economic variables. The basic data gathered from the National Bank of Slovakia data portal consists of the real and nominal output, nominal capital, output price and different interest rates. A challenge is to find real capital time series. One way is to use a net investment deflator computed from the real and nominal gross fixed investment and the consumption of the fixed capital. The low-pass filter of data series is used to measure the long-run value of variables.

Keywords: long-run elasticity of substitution, low-pass data filter, Slovak economy, capital demand, first order condition of the profit maximising firm

JEL classification: C23, E22, E25

Acknowledgments: This paper is supported by the Grant Agency of Slovak Republic VEGA, grant no. 1/0444/15 "Econometric Analysis of Production Possibilities of the Economy and the Labour Market in Slovakia".

\section{Introduction}

The importance of the elasticity of substitution coefficient is large. Chirinko et al. (2014) highlight the importance with the rich literature review. For example, a crucial assumption of Piketty (2014) is that the elasticity of the substitution between labour and capital is more than 1. However, a novel empirical research contradicts this assumption. Klump et al. (2007) estimated the system of equations consisting of the CES production function linearization and two first-order conditions of a firm maximising its profit. Authors accentuate the production function normalisation and a biased technological change concept. Chirinko et al. (2014) propose an approach of the coefficient of the elasticity of the substitution estimation dealing with the first-order condition of the firm maximising its profit corresponding to the capital. Authors modify their data series by the low-pass filter to abstract them from the business cycles and the short-term effects driven by different underlying processes. They prove that the approach meets the production function normalisation and they observe that considering a biased technological change does not affect the result elasticity of substitution estimate. Finally they observe that the method can be used for aggregate data. Both studies estimate low value of the elasticity of substitution in the U.S. economy: 0.60 by Klump et al. (2007) and 0.40 by 
Chirinko et al. (2014). The literature review of the past empirical studies estimating the production function coefficients provide Chirinko (2008) or Klump et al. (2012). In the paper we choose the approach of Chirinko et al. (2014) to estimate elasticity of substitution in Slovak economy.

\section{Data and Methodology}

The estimation form derived from the first-order condition of the firm maximising its profit corresponding to the capital demand can be written as follows:

$$
y_{t}=\beta_{0}+\beta_{1} x_{t}+\beta_{2} t+u_{t}
$$

where $y_{+}$corresponds to the capital/output ratio, $x_{t}$ corresponds to its relative prices (capital price/output price ratio). To fit the formula with the first-order condition of the firm, both variables are measured by their natural logarithms. To eliminate the effects of different underlying economic processes, ensuring the exogeneity of the price ratio $x_{t}$, both variables are measured by the proper long-run values. As Chirinko et al. (2014) argue, these values can be reached using Low-Pass filter. The elasticity of substitution is the negative value of the $\beta_{1}$ coefficient.

\section{Data}

Electronic macroeconomic database of the National Bank of Slovakia provide the quarterly capital stock data series estimate. The data series is in current prices and seasonally adjusted. Therefore we use this portal to gather all other quarterly data series. All gathered data are seasonally adjusted except interest rates. To assure the correctness of our process, we normalised all used price deflators to the value 1 in the 2010:Q4 period and re-computed the data-series in constant prices. We use real seasonally adjusted GDP and its deflator to measure the output volume and its price.

The challenge is to find the volume of capital, while the dataset of the capital stock is in current prices. For this purpose, we firstly need to compute the net investment deflator. The net investment in current prices is measured as the first difference of the capital stock. Let us define a net capital creation as the difference between gross capital creation and the consumption of the capital. We computed the net capital creation in both current and constant prices and so we gathered the net capital formation deflator. The deflator we use to compute net investment in constant prices from the nominal net investment. As our deflators are normalised for the 2010Q4 period, the capital stock in constant prices equals to the capital stock in current prices in this period. Subtracting the net investment from capital stock in constant prices, we gain the capital stock in constant prices before this period, and, reversely, cumulating the net investment to the capital stock in constant prices we gain capital stock in constant prices after this period. The capital price is the sum of interest and depreciation rates. We use the interest rate on loans to non-financial corporations and interest rate on deposits of non-financial corporations. According to the two interest rate data series we have two dataset versions. We measure the depreciation rate as the consumption-of-the-fixed-capital/capital-stock ratio in constant prices.

Baxter and King (1999) suggested appropriate low-pass filter. The filter is sensitive to the selection of frequency length (lead/lags) for the moving average, and the low and high values for the cycle period. We use the frequency respond function to find that Baxter and King's suggested selection of 3 year frequency length $q$ (12 quarters), 1.5 year (6 quarters) low and 8 year (32 quarters) high cycle period is proper. We made experiments filtering data with other combinations of the frequency length and cycle periodicity. Our dataset uses the period $1997-2014$ (2 $2^{\text {nd }}$ quarter). After filtering we lose the first $q$ and the last $q$ observations. 


\section{Methodology}

By our exogeneity assumption on the price ratio $x_{t}$, the ordinary least square method is suitable to estimate the form Error! Reference source not found.. Since the low-pass filter creates overlapping observations, the stochastic term is serially correlated. We achieve the effective estimate using auto-regressive terms or we compute standard errors with the procedure of Newey and West (1994). These two different processes do not change our results. The unit root of residuals is tested by the augmented Dickey and Fuller and Phillips Peron tests (see Lukáčik et al. 2008) stating that residuals are stationary. We prefer the later test, if many autoregressive terms solved autocorrelation in the test specification.

Sort of problematic are the exogeneity assumption of the price ratio $x_{t}$ and $a$ stochasticity assumption of the term Ut. The supply system can be expressed by other first-order condition of the firm and by the lone production function. These two relations may be related with our estimation form. Moreover the supply and demand system of equations can be simultaneous. Therefore we also estimated the estimation form Error! Reference source not found. by the generalised methods of moments with the instrument set including constant trend and two lags of both ratios $y+$ and $x+$

\section{Results}

Our estimates are expressed by the following two equations.

$$
\begin{array}{ccc}
y_{t}=0.011-0.136 x_{t}^{L}-0.0004 t+u_{t} & \mathrm{R}^{2}=0.562 \\
& {[0.009][0.049] \quad[0.0003]} & \\
y_{t}=0.023-0.082 x_{t}^{D}-0.0007 t+u_{t} & \mathrm{R}^{2}=0.664 \\
& {[0.007][0.021] \quad[0.0002]} &
\end{array}
$$

where the uppers correspond to the use of the interest rate on loans to $(L)$ or deposits of (D) non-financial corporations in datasets. The standard errors in the brackets are computed with the procedure of Newey and West (1994). The elasticity of substitution is about 0.14 using the first dataset and about 0.08 using the other one.

\section{Discussion}

Comparing our results with the novel estimates around the world, the Slovak elasticity of substitution is relatively low. However, the reviews of other empirical papers provided by Chirinko (2008) and Klump et al. (2012) admit such low values. We estimated the equation Error! Reference source not found. using different combinations of the frequency length and cycle periodicity. As well as Chirinko et al. (2014), we state that the estimated value of the elasticity substitution is increasing with the periodicity. However, the estimated values are below the estimates of mentioned novel papers.

Jürgen (2009) provide a possible explanation of low Slovak elasticity of substitution. Using a theoretical model with micro-foundations he assumes a lower elasticity of substitution in transition economy. We assume that Slovakia has been the transition state in the study period. Using neoclassical growth conceptual schema, all events like the transition from central planned economy to the market economy, opening to the western European markets, entrancing to the European monetary Union, labour tax reforms have changed the Slovak steady state and have started Slovak transition move to its new steady state. In fact, using $\beta$-convergence 
estimation form of Barro et al. (2003), Szomolányi et al. (2011) observed that Slovakia has been in the transition state in the study period. The limitation of the study comes from the exogeneity assumption of the price ratio $x+$ and a stochasticity assumption of the term Ut. However the use of the generalised method of moments does not change our state that Slovak elasticity of substitution is relatively small.

\section{Conclusion}

The Slovak elasticity of substitution is relatively small. This information is surely helpful for Slovak policymakers. As Chirinko et al. (2014) state, low value of the elasticity of substitution suggests that "the convenient and all too often conventional assumption of a Cobb-Douglas production function used in many areas of economic analysis needs to be abandoned. DSGE models that maintain (the unit elasticity of substitution, note of the authors) amplify the true effect of price movements including the traditional channel of monetary policy - relative to a model based on a lower value of this elasticity. Tax simulation models using Cobb-Douglas production functions impart a similar upward bias to the effects of tax cuts. A departure from a Cobb-Douglas production function will force an expansion of the neoclassical growth model to include, among other factors, a central role for directed technical change that affects factor shares and balances growth."

Our study opens other questions. Is Jürgen's (2009) hypothesis of the dual elasticity of substitution in transition and steady state relevant? Can this concept re-explain the neoclassical growth theory? Answering these questions would be helpful for the policymakers in Slovakia and other post-communist countries in transition state.

\section{References}

1. Barro, R. J., Sala-i-Martin, X. (2003), Economic Growth, MIT Press (2nd edition), Cambridge, Massachusetts, London, England.

2. Baxter, M., King, R. G. (1999), "Measuring Business Cycles: Approximate Band-Pass Filters for Economic Time Series", The Review of Economics and Statistics, Vol. 81 No.4, pp. 575-593.

3. Chirinko, R. S., (2008), " $\sigma$ : The long and short of it", Journal of Macroeconomics, Vol. 30 No.2, pp. 671-686.

4. Chirinko, R. S., Mallick, D. (2014), "The Substitution Elasticity, Factor Shares, Long-Run Growth, and the Low-Frequency Panel Model", CESifo Working Paper Series 4895, CESifo Group Munich, July 2014.

5. Jürgen, A. (2009), "A Dual Elasticity of Substitution Production Function with an Application to Cross Country Inequality", Economics Letters, Vol. 102 No.1, pp.10-12.

6. Klump, R., McAdam, P., Willman, A. (2007), "Factor Substitution and Factor Augmenting Technical Progress in the US", Review of Economics and Statistics, Vol. 89 No.1, pp. 183-192.

7. Klump, R., McAdam, P., Willman, A. (2012), "The Normalized CES Production Function: Theory and Empirics", Journal of Economic Surveys, Vol. 26 No.5, pp. 769-799.

8. Lukáčik, M., Lukáčiková, A. (2008), "Význam testovania stacionarity v ekonometrii", Ekonomika a informatika, Vol. 6 No.1, pp. 146-157.

9. National Bank of Slovakia (2017), "Macroeconomic database", available at: http://www.nbs.sk/en/monetary-policy/macroeconomic-database/macroeconomicdatabase-chart (3 March 2017)

10. Newey, W. K., West, K. D. (1987), "A Simple, Positive Semi-definite, Heteroskedasticity and Autocorrelation Consistent Covariance Matrix", Econometrica, Vol. 55 No. 3.

11. Piketty, T. (2014), Kapitál v 21. storočí, Ikar, Bratislava.

12. Szomolányi, K., Lukáčiková, A., Lukáčik, M. (2011), "The $\beta$-convergence of the EU27 Countries", in Proceeding of $29^{\text {th }}$ International Conference on Mathematical Methods 
in Economics 2011, Janská dolina, Slovakia, Professional Publishing, Praha, Czech Republic, pp. 287-291.

\section{About the authors}

Karol Szomolányi was born in Bojnice in the Slovak Republic (formerly Czechoslovakia) in 1976. He is an associated professor of operations research and econometrics at University of Economics in Bratislava, Faculty of Economic Informatics, Department of Operations Research and Econometrics. He is a member of the Slovak Society for Operations Research. He deals with the macroeconomic analysis and econometrics. His areas of interest are real business cycle models and dynamic stochastic macroeconomic models and their use for developing countries of Eastern Europe. Author can be contacted at karol.szomolanyi@euba.sk.

Martin Lukáčik was born in Žilina in the Slovak Republic (formerly Czechoslovakia) in 1974. He is an associated professor of operations research and econometrics at University of Economics in Bratislava, Faculty of Economic Informatics, Department of Operations Research and Econometrics. He is a president of the Slovak Society for Operations Research. He deals with the econometric methods in macroeconomic framework and time series econometrics. His areas of interest are VAR models used in macroeconomics and forecasting methods. Author can be contacted at martin.lukacik@euba.sk.

Adriana Lukáčiková was born in Gelnica in the Slovak Republic (formerly Czechoslovakia) in 1971. She is an assistant professor of operations research and econometrics at University of Economics in Bratislava, Faculty of Economic Informatics, Department of Operations Research and Econometrics. She is a member of the Slovak Society for Operations Research. She deals with the computable general equilibrium models and econometrics. Her area of interest is econometric modelling of national economy. Author can be contacted at adriana.lukacikova@euba.sk. 